\title{
Electroacoustic Music in Mexico
}

Rodrigo Sigal

Centro Mexicano para la Música y las Artes Sonoras, Mexico

\begin{abstract}
Mexico has been an outsider to the electroacoustic music movement. Countries like Argentina, Cuba and Chile were pioneers in establishing electronic music centers in the continent. This texts aim to illustrate briefly the story behind the first initiatives in Mexico andthe actual situation and characteristics of the institutional electroacoustic music scene.
\end{abstract}

[Keywords: electroacoustic, music, Mexico.]

Mexico has a unique musical heritage influenced by a meld of ancient indigenous Mexican and European musical traditions. Contemporary trends continue to reflect a great diversity of regional and national styles. Adaptation of European musical approaches began during the colonial period, in the 16th and 17th centuries, continuing through the present. Among the emerging musical developments in Europe and North America to which contemporary Mexican composers have responded are electronic and computer music.

The birth of electronic music in Mexico may be tied to three developments: the composition of the first electronic work by a Mexican composer and the invention, in Mexico, of the first synthesizer in Latin America, both around 1960; and the opening of the first electronic music studio, in 1970. The first electronic music work by a Mexican composer was realized by Carlos Jiménez Mabarak, in 1960, followed by music by Eduardo Mata, Jorge Dàjer and Guillermo Noriega in 1963, José Antonio Alcaraz in 1964, Blas Galindo in 1965, Héctor Quintanar and Manuel de Elías in 1967, Carlos Chávez and Francisco Nunez in 1968, and Manuel Enriquez (who was particularly prolific), Alicia Urreta and Mario Lavista in 1969. It was also during the 1960s that the first public concerts of electronic music were programmed in Mexico.

The National Conservatory of Music's Electronic Music Lab opened its doors in 1970. The Lab was founded by Raoúl Pavón and Héctor Quintanar. Quintanar, a noted composer who served as artistic director and Pavón, who built the Omnifón, the first synthesizer in Mexico, during the 1960s and served as technical director. Composers who worked in the Lab during its early days included Quintanar, Eduardo Mata, Mario Lavista, Manuel de Elías, Francisco Nunez and Julio Estrada. Resources in the original Lab included Buchla and Moog synthesizers. Over the years, the lab moved to two other sites, subsequently returning to the Conservatory in 1992. A problem faced by the Lab has been the Conservatory's failure to fund the ongoing maintenance, staffing and educational planning of the studios. Since technology requires

Rupkatha Journal on Interdisciplinary Studies in Humanities (ISSN 0975-2935), Vol 2, No 3, 2010

URL of the Issue: http://rupkatha.com/v2n3.php

URL of the article: http://rupkatha.com/V2/n3/ElectroacousticMusicinMexico.pdf

(c) www.rupkatha.com 
constant investment in order to remain in operation, the studios ceased to be useful after a time.

Among electronic music composers of the younger generation are Antonio Russek, Manuel Rocha Iturbide, Javier Alvarez, and Rodrigo Sigal. Additional labs have existed since the 1980s at the Fine Arts National Institute (Escuela Superior de Musica del Instituto Nacional de Bellas Artes, aka INBA) Superior School of Music, at CIIM (Centro Independiente de Investigacion y Multimedia, in English Independent Center of Research and Multimedia), a private studio operated by Antonio Russek and Vicente Rojo and outside Mexico City, at the Computer Music Lab in Guanajuato and at the University of Querètaro. Compositional activities have also taken place recently at the National Center for the Arts (Centro Nacional de las Artes) Center for Multimedia (Centro Multimedia) in Mexico City and the new Mexican Center for Music and Sonic Arts in Morelia, Michoacán.

Within the academic environment, there have been recent efforts to start graduate courses in electroacoustic composition, a novelty for Mexico and more broadly in Latin America. Computer music festivals are being organised, and the major mainstream contemporary music festivals are therefore beginning to program electroacoustic music. Mexico's musical establishment is undergoing a slow, but noticeable process of change as young composers discover technology and multidisciplinary projects.

Mexico, as a home for computer music, is at an important crossroad. Mexican institutions, like those in some other countries, have focused on computer music solely from the perspective of technological resources, rather than within a broader context of musical, aesthetic and educational concerns. Thus, the focus of institutional support for computer music has been funding for computer equipment rather than on long-term planning and structured educational projects. It is my belief that institutions should concentrate not just on technology, but rather on strategies for its new creative use. Participating in the permanent race to acquire the latest equipment is not useful. As has often been the case throughout Latin America, governments provide initial investment but not ongoing funding for studios. Bureaucracy, inadequate funding and unwieldy administrative rules have contributed to the inefficiency of studios. Fortunately, since faculty members often have secured funding for research projects, some of the studios have been able to survive and at times grow incrementally.

Fortunately, some of the most important musical technologies are now affordable for individual composers. Even so, the costs of music technology have always depended on access to social and economic status. Those lacking basic life needs cannot invest money in machines. Nonetheless, students and composers have acquired their own personal computers and 
equipment so that they can work in their own studios. It is thus my contention that electroacoustic music labs in Mexico and elsewhere should no longer be considered as providers of technology. I believe that we should think of and make again these spaces as centers where composers can meet and conduct research. The new electroacoustic music labs in Latin America must be conceived as physical spaces where composers can gain access to knowledge and experience, not access to computers.

One fruitful function of new Latin American computer music labs is to serve as centers providing professional quality sound systems. Since few composers own advanced studio monitors or have access to spaces with excellent acoustics, this is an important service that Labs can provide. To make the best use of existing technologies in the Labs, investment must be made in human resources and academic planning, to make the most effective use of those technologies.

It is important to embrace a broad, inclusive vision of electroacoustic music in Mexico. Cultural programs that began more than a decade ago to support artists with grants, commissions and study fellowships have begun to slowly integrate disciplines that use technology, among them electroacoustic music. The first two generations of Mexican composers who engaged in postgraduate studies in computer music abroad have been returning to Mexico and integrating themselves into the Mexican contemporary music scene. In fact, most Mexican composers and sound artists and their attending aesthetic perspectives are not part of academia. A complex mixture of artistic approaches inclusive of traditional computer music and laptop performance, installation and other sound art forms must be viewed as part of one discipline.

There is a substantial difference between Mexico City itself and the rest of the country. Very little has been done outside the capital city to promote computer music. This has had positive and negative consequences. Until recently, investment in resources was limited to Mexico City. As a result, many composers, especially students, have had to choose between moving to Mexico City and not having access to needed technologies. However, this lack of resources has led many composers outside the capital to engage in collective projects and efficiently share available technology. Affordable equipment will lead to further shared resources and collaborative projects and performances. This has happened for a long time in places, most notably the border city of Tijuana, where non-academic music collectives have grown and effectively promote their work within Mexico and abroad.

Mexico is a large country, filled with tremendous musical and artistic energy. Mexico has chased technology for a long time. Computer music technology has arrived in Mexico. We are now at an important moment when 
Mexican composers and institutions have the opportunity to incorporate these new technologies in new and novel ways. This is also a key moment to reassess how academic and other musical institutions can reassess policies governing the use of available resources and most effective ways to tap the musical creativity of Mexican composers and performers.

\section{References}

Alvarez, J. (1996). "La Música Electroacústica en Mexico." In Pauta. Cuadernos de teoría y crítica musical, Vol. XVI, Number 57-58. Mexico: CONACULTA - INBA.

Carredano, C. (2003). "Rodrigo Sigal. Cronología. Catálogo. Referencias Documentales" In Pauta. Cuadernos de teoría y crítica musical, Vol XXI, Number 85, 59-73. Mexico: CONACULTA - INBA.

Dal Farra, R. (1996). "Electroacoustic and Computer Music in Latin America." In Proceedings of the International Computer Music Conference 1996, 165-168. Hong-Kong: International Computer Music Association.

Odgers, A. (2000). Tesis: La Música Electroacústica en Mexico. Mexico: Escuela Nacional de Música.

\section{Other Sources}

Manuel Rocha Iturbide, "Cronologia comparada, historia de la música electroacústica en México," on the web at http://www.artesonoro.net.Ricardo Dal Farra, "Latin American Electroacoustic Music Collection," on the web at http://www.fondation-langlois.org.

Rodrigo Sigal is the Director of Centro Mexicano para la Música y las Artes Sonoras (Mexican Centre for Music and Sonic Arts). 